\title{
Vladimir P. Amalitsky and Dmitry N. Sobolev - late nineteenth/ early twentieth century pioneers of modern concepts of palaeobio- geography, biosphere evolution and mass extinctions
}

\footnotetext{
${ }^{1}$ Laboratory of Palaeobiology, University of Opole, Oleska 22, 45-052 Opole, Poland; *Corresponding author, E-mail: eyazykova@uni.opole.pl ${ }^{2}$ Department of Palaeontology and Stratigraphy, Faculty of Earth Sciences, University of Silesia, Będzińska 60, 41-200 Sosnowiec, Poland, E-mail: grzegorz.racki@us.edu.pl
}

(Received: October 12, 2016; Revised accepted: December 30, 2016)

http://dx.doi.org/10.18814/epiiugs/2017/v40i3/017022

The great palaeontological achievements of the Russian scientists Amalitsky and Sobolev, who worked in Russia and Poland at the turn of nineteenth and twentieth centuries, have previously been outlined in detail. However, their original and surprisingly modern concepts of the development of life on earth have received far less attention. Amalitsky was one of the first scholars who considered the intimate relationship between floral and faunal evolution and the interdependence between a developing biosphere and geological processes. In fact, he documented, for the first time, the existence of a single palaeobiogeographical province during the Permian Period, which we now refer to as the supercontinent Pangaea. In 1896, Amalitsky's main idea was that there were extended periods of gradual change in topography and biosphere of the earth, but that it was orogenic activity that had a marked impact on biotic crises. His pupil at Warsaw University, Sobolev, followed up on his work, and in fact came up with the theory of neocatastrophism in 1928. Thus, Amalitsky's model predates the concept of cyclic evolution of the biosphere in dependence on orogenic cycles, with a prime role for volcanism, which is currently well known as the "volcanic greenhouse". Sobolev also recognised four main mass extinctions, i.e., the late Ordovician, the late Devonian, the late Triassic and the Cretaceous/Paleogene ones, but somehow he 'missed out on' the end-Permian catastrophe.

\section{Introduction}

Vestigia sémper adóra (Always worship the past)

(Fivaida, song XII, linr 817, Publius Papinius Statius (AD c. 45-c. 96))

Numerous 'modern' theories in fact already were formulated more than one hundred years ago. Naturally, in those days they were strongly criticised, satirised or just simply ignored. Many scholars from the nineteenth, or even from the seventeenth and eighteenth centuries, were pioneers of scientific theories that became subsequently accepted by the scientific community (see examples in Racki (2014, 2015), and references therein). For example, a short note in Russian, published in 1916 by the young Estonian astronomer Ernst Julius Öpik, was among the seminal contributions to the inadequate understanding of meteorite cratering mechanics of the time, but mostly because of the language barrier and the troubled times, it remained almost unread and was often quoted erroneously (Racki et al., 2014). In fact, another forgotten Russian scholar, Nikolai A. Morozov, was certainly the true initiator of Öpik's explosive impact theory.

In the present paper we focus on two famous Russian palaeontologists who worked not only in Russia, but also held positions in Poland and in the Ukraine at the turn of nineteenth and twentieth centuries: Vladimir P. Amalitsky (1860-1917), the great teacher, and Dmitry N. Sobolev (1872-1849), his deserving student. Both scientists were remarkable palaeontologists who worked at Warsaw University in the Kingdom of Poland, an autonomous state closely linked to the Russian Empire. During the First World War, both Amalitsky and Sobolev were repatriated to Russia. Sobolev's scientific carrier came to a complicated end at Charkov University in Soviet Ukraine.

At the time, both scientists were well known both in Russia and the Soviet Union, and yet are now largely 'forgotten'. Their achievements mostly concerned two groups of extinct macrofossils, the Permian vertebrates and Devonian ammonites, respectively. Yet, their true contributions are of a much wider range and surprisingly akin to modern standards in the earth sciences, as outlined in the present paper.

\section{Biographic Preamble}

\section{The Teacher}

Vladimir P. Amalitsky (Fig. 1) was born in the village of Stariki (Zhitomir region, Ukaine) on July 1, 1860. Three years later the family moved to Russia. In 1879 he joined the Natural History Department in the Physics and Mathematics Faculty of Sankt Peterburg Imperial State University, and took up a specialisation in the earth sci- 


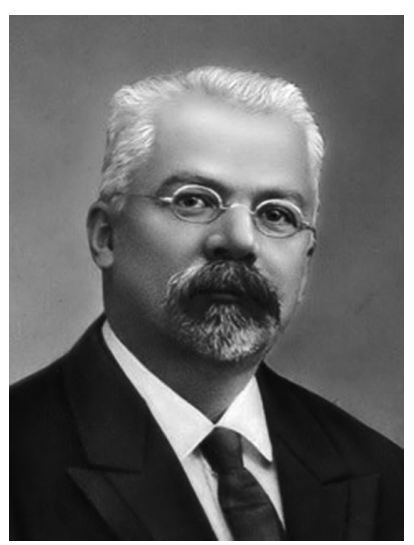

Figure 1. Vladimir Petrovich Amalitsky. (http://www.museum-21.ru/ info/amalitsky.html).

ences (Efremov, 1960). He was a student of renowned professors such as A.A. Inostrantsev and V.V. Dokuchaev, who recognised his talents and even allowed him to provide some lectures for younger students (Efremov, 1960). In 1883, Amalitsky graduated from the university as a petrologist, not a palaeontologist, having successfully defended his master's thesis entitled, 'Chemical analysis of granites from southern Russia'. Subsequently, he was invited to stay on as a university lecturer and in 1886 he became curator of the Geological Cabinet at the university. From 1884 onwards, he took part in annual geological expeditions to the Nizhny Novgorod area at the invitation of the Russian geologist Vasily Dokuchaev (Efremov, 1960). This was a good practical educational experience for Amalitsky but the most important result of this trip was that he collected some fossils, mostly bivalves, from terrestrial sedimentary rocks of Permian age that had previously been considered absolutely barren (Amalitsky, 1885; Dokuchaev, 1886). In doing so, he broke away from the traditional views concerning the nature of these Permian rocks and became the first to start collecting fossils from such deposits, including also numerous vertebrate remains. Every year he published the results from these expeditions (Amalitsky, 1886, 1887), while during the VIII Meeting of Russian Naturalists in 1890 he presented palaeoecological and morphological studies of Permian bivalves. This was the first time that he publically announced his hypothesis of the intimate connection between floral and faunal evolution and the dependence of the developing organic world on geological processes in the global ecosystem (Amalitsky, $1890 \mathrm{a}, \mathrm{b})$. In 1890 he obtained the position of professor at Warsaw University and became chief of the Department of Geology. In those days, the geological museum at the department was very poor. In fact, the museum held only a single collection, that of a Polish geologist of German descent, Jerzy Bogumił Pusz (Georg Gottlieb Pusch). Together with his students, Amalitsky started collecting fossils, thus increasing the museum holdings, even purchased some fossils out of his own pocket (Amalitskaya, 1925). The subsequent year Amalitsky visited the Dresden Royal Museum and the Munich Palaeontological Museum as well as the private collection of Dr Roder, in order to study Permian bivalves. In 1892 he successfully defended his dissertation (Doctor of Sciences; doctor nauk) at St Petersburg University entitled, "Materials for understanding Permian fauna of Russia". In 1908 he was appointed director of the Warsaw Polytechnic Institute and continued to acquire fossils for the Palaeontological Museum. As a con- sequence, his collection steadily grew (Amalitsky, 1900, 1901a, b, 1903). However, in 1914 the First World War broke out and he tried to salvage the unique collection of fossils by evacuating the Warsaw Polytechnic Institute to Nizhny Novgorod. Unfortunately, the Soviet Socialist Revolution followed in October 1917 and the general politics of the country changed and the Warsaw Polytechnic Institute was renamed Nizhny Novgorod Polytechnic Institute. Amalitsky refused from his position as director. As a result, his career was finished and he fell ill. Amalitsky attempted to convalesce at Kislovodsk, but died on December 28, 1917, aged 57 (Amalitskaya, 1925). Amalitsky's fossil collection was then moved to Leningrad and became part of the Museum at the Department of Historical Geology at the Geological Faculty of Leningrad State University (LGU). During the Second World War, part of this lot was moved to the Moscow Palaeontological Institute (PIN) of the Russian Academy of Sciences.

\section{The Student}

Amalitsky had numerous students who subsequently became famous geologists. Dmitry N. Sobolev (1872-1949) was one of them. He continued the work of his professor, adopting his main ideas and providing a detailed study of earth ecosystem crises and the underlying causes.

Dmitry Sobolev (Fig. 2) was born in the village of Chripeli, Kostroma guberniya, in 1872. He graduated as a candidate of Natural Sciences (gold medal) from Warsaw State University in 1899. Sobolev was fascinated by Amalitsky's ideas and always helped his teacher, which is why, in 1899, he took up the position of Assistant at the Department of Geology of Warsaw State University. Interestingly, similar to his teacher, he was not a palaeontologist from the very beginning. In 1911, he defended his master's thesis at Moscow State University entitled, "Middle Devonian of Kielce-Sandomierz Upland" and obtained the degree of master of mineralogy and geognosy. Like his teacher, he subsequently became interested in fossils and described numerous new species, in particular ammonites, from the Devonian of Poland and the Ukraine (Ozonkowa, 1980). In 1914 he presented his doctoral dissertation at Kiev State University entitled, "Sketches on the phylogeny of goniatites" (Sobolev, 1914b) in which he formulated and described his original evolution concept, predicting many notions of

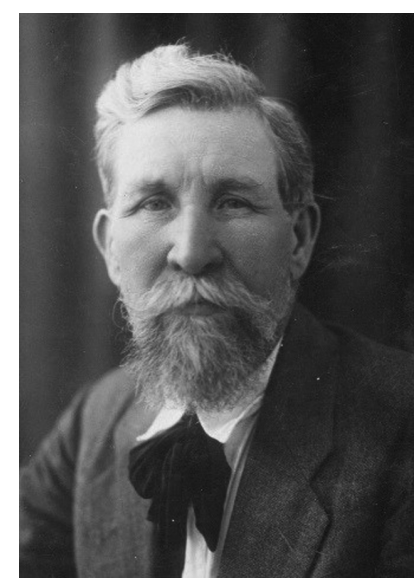

Figure 2. Dmitry Nikolaevich Sobolev as Professor of Geology at the University of Kharkov (photograph courtesy of the University of Kharkov). 
the theory of nomogenesis. That theory was later described by Berg (1922), but Sobolev never subscribed to the view that his ideas were the same as Berg's theory (Sobolev, 1914a; see review in Popov, 2008). Unfortunately, Sobolev's dissertation had two negative reviews and was unsuccessful. Only in 1934 did he obtain a doctoral degree. Despite this, he became chief of the Department of Geology at Kharkov State University, where he actually founded the school of geology (Solovyev et al., 2014; see also http://geologia.univer.kharkov.ua/ index.php/about-us/vidatni-spivrobitniki). Dmitry Sobolev died at Kharkov on March 16, 1949, at the age of 77.

\section{New 'Old' Ideas}

Both Amalitsky and Sobolev proposed ground-breaking ideas in the fields of palaeogeography, ecosystem evolution and global event stratigraphy, that have been largely overlooked by Western scientists. In addition, these concepts are also barely known in Russia even to this day.

\section{Amalitsky's Contributions}

As noted above, at St Petersburg University in 1892 Vladimir Amalitsky defended his thesis entitled, "Materials for understanding Permian fauna of Russia". The largest portion of this work was published in Warsaw, but not the complete version. He planned to publish a series of volumes documenting the Permian fauna, but unfortu- nately only the one on the bivalve family Anthracosiidae Amalitsky, 1892 appeared in print (Amalitsky, 1892).

In that volume, he first carefully studied and described the morphology of a wealth of Permian bivalves from Russia. The material studied originated from his own collection as well as from collections of St Petersburg State University and St Petersburg Mining Academy. Results of this study included a biostratigraphical subdivision of the Permian System in Russia and a review of all Permian bivalves known at the time. The study also documented the similarity of South African and Indian Permian Glossopteris flora based on the works of Suess, Neymar and Owen. This allowed Amalitsky to draw the conclusion that, "...fresh water sediments of Karroo-Formation...and socalled layers "Damuda Schichten" from Gondwana-group...could be correlated with Permian marl-sandy formation of Russia. ... similarity of organisms widely distributed in Permian sediments of Russia and Karroo-Formation in India, such as Palaeomutella, should...give a more or less certain basis for the correlation of Permian fresh-water deposits of Russia and Africa" (Amalitsky, 1892, p. 149). Karl (von) Zittel proposed publishing a shortened version of this work in German, to be translated by Amalitsky's wife (Amalizky, 1892).

Amalitsky travelled to England in 1894-1895, where he worked at the British Museum (Natural History, London), and found final proof for his theory that the Late Permian bivalve fauna from the marl-sandstone formation in Russia was almost the same as that from the Lower Karroo-Beaufort beds and Kimberley shales (Amalitsky, 1895a). Moreover, he proposed "the existence in Permian epoch the non-inter-

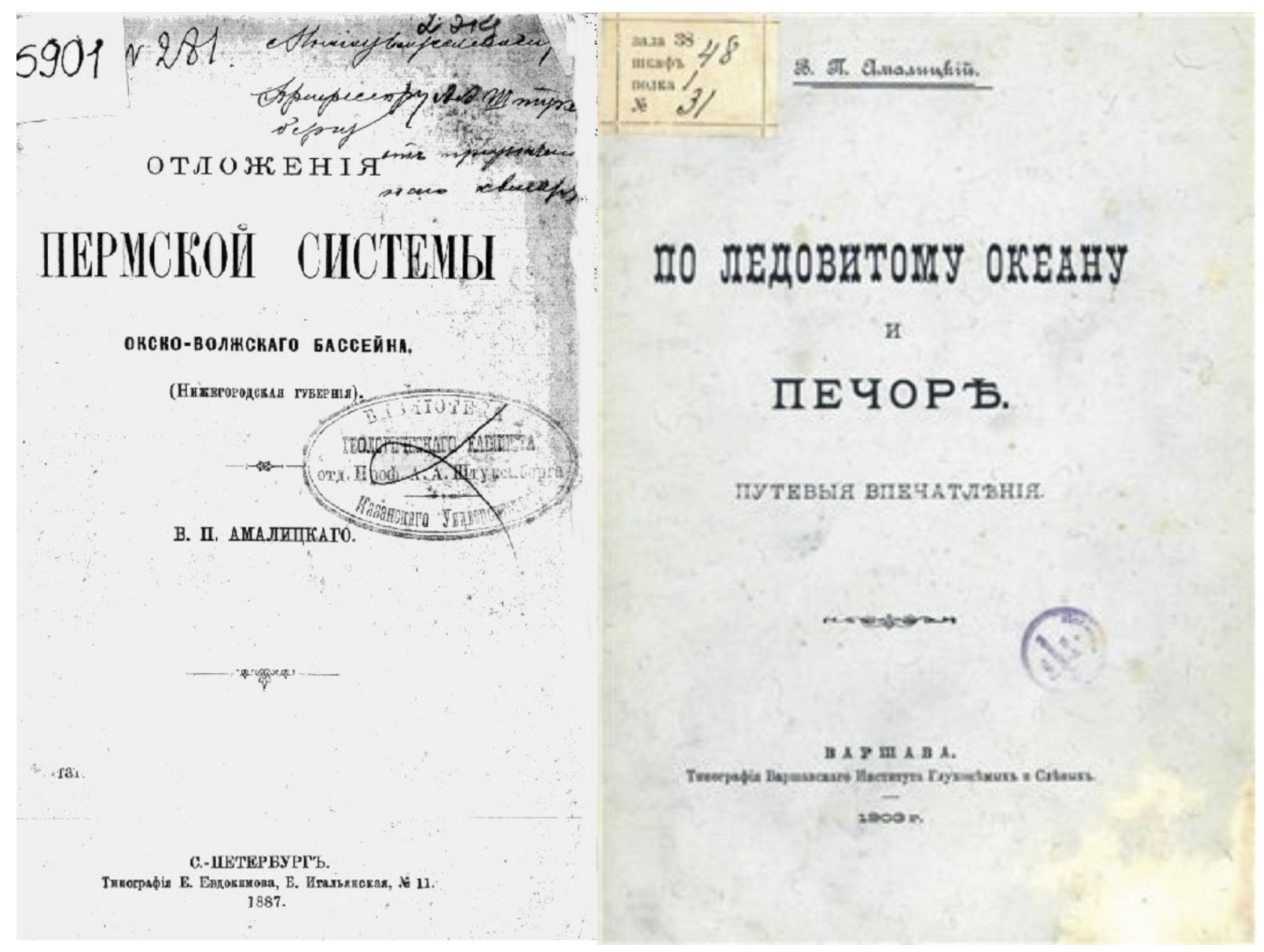

Figure 3. Title pages of two of Amalitsky's books on the Permian System in Russia. 
rupted Russian-Indo-African continent' (Amalitsky, 1895b, p. 339) and the similarity between Late Permian remains of vertebrate fossils, predominantly reptilian, from terrestrial sediments in Russia and Theriodontia from coeval rocks in Africa (Amalitsky, 1895a, b).

In 1896, during a special meeting at Warsaw University, he delivered a talk entitled, 'About the geological development of the landscape of the earth and its organisms'. However, his idea of a single, large supercontinent was still not embraced by the scientific community. For proof to back up his theories he continued to do fieldwork in 1895-1897, funded by personal money and accompanied only by his wife (Amalitsky, 1897). They collected material from Upper Permian deposits along the rivers Vitegra, Sichon and Severnaya Dvina. The second year of the field campaigns was the most successful because plant remains, identified as the Glossopteris flora were discovered, as well as the first poorly preserved reptile skull, "it is probably Pareiasauria.... we found a few vertebrae, part of the skull and part of the jaw with very well-preserved original teeth" (Amalitsky, 1897).

Only in August 1897 did he bring straight from the field his collection of Permian vertebrate fossils (Figs. 4-6) and put these on exhibit during the VII International Geological Congress at St Petersburg. He did not deliver a talk at that time, but the well-known researcher of Permian vertebrates from South Africa, H.G. Seeley, lectured on September 3, specifically underlining the presence of fossils in Amalitsky's collection that belonged to dicynodonts and pareiasaurs which illustrated their similarity to Permian fauna from Africa (Seeley, 1899). The same notes about his collection were made in reports by other specialists (e.g., Zeiller, 1898). From that time onwards, his theory of a supercontinent during Permian times was accepted. In 1902 Amalitsky became an honorary academic member of the Royal Society of London. Some of the reports and notes from his numerous field trips were published only after his death (Amalitsky, 1921a, b, 1922a, b, 1927, 1931)

Today, Amalitsky's contribution to research fields such as palaeogeography, palaeozoography or biosphere evolution in general cannot be overestimated. The most interesting aspect would appear to be his view that, "long periods of gradual changes in the Earth's land-

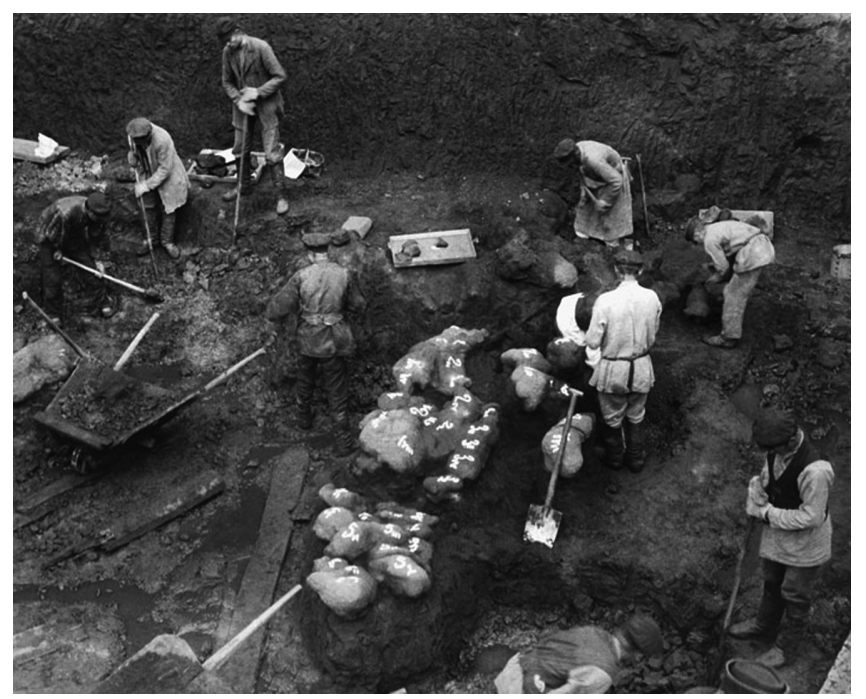

Figure 4. Amalitsky's field camp in 1899. (Picture from archives of the Palaeontological Institute in Moscow (PIN RAN); http://kotlaslib.aonb.ru/rai-pam-Amalitskyv.html).

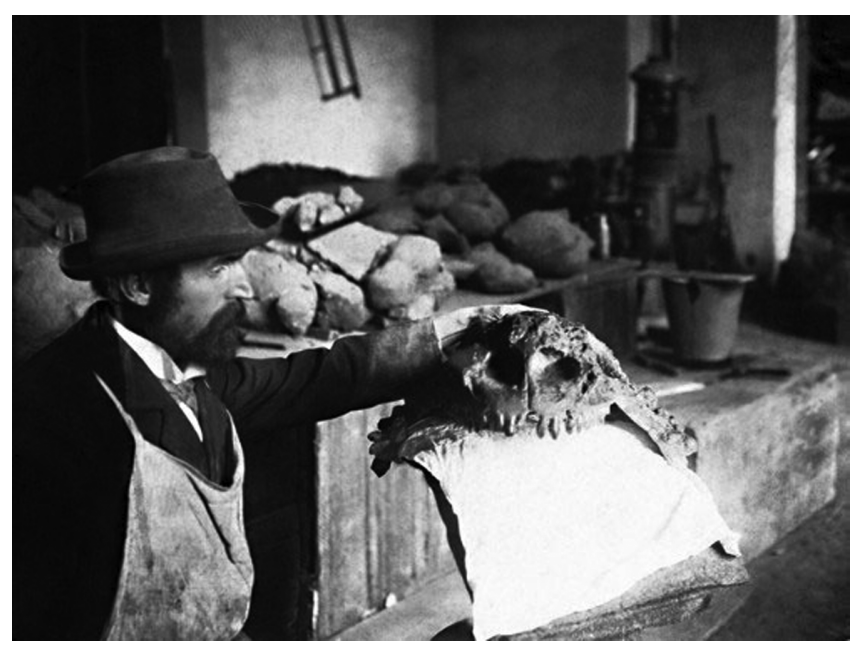

Figure 5. Skull of Scutosaurus in the Library of the University of Warsaw (Picture from archives of Palaeontological Institute in Moscow (PIN RAN); http://kotlaslib.aonb.ru/rai-pam-Amalitsky.html).

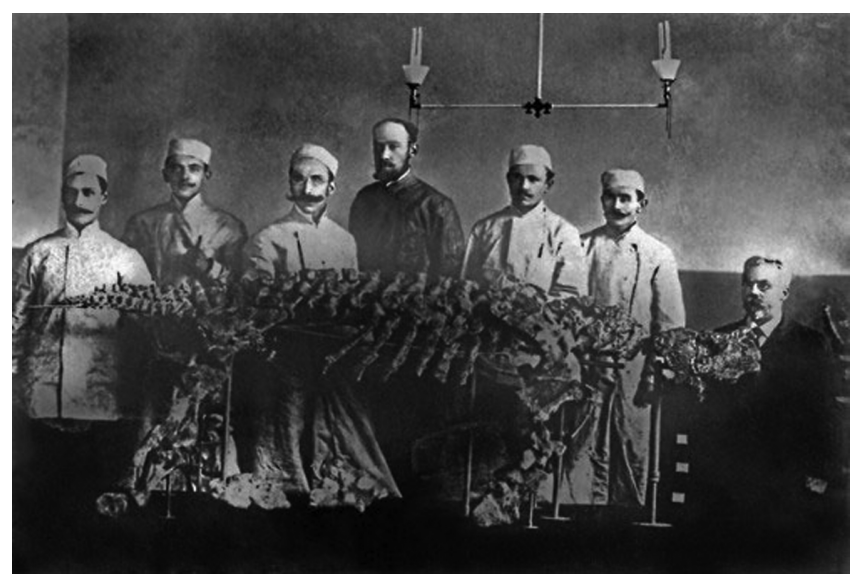

Figure 6. First prepared skeleton of Scutosaurus. V.P. Amalitsky is the first person on the right (Picture from archives of Palaeontological Institute in Moscow (PIN RAN); http://kotlaslib.aonb.ru/rai-pamAmalitskyv.html).

scape correlate with the comparatively smooth development of living organisms, and only episodes of orogenic activity had an impact on the dramatic transformation of the biosphere" (Amalitsky, 1896, pp. 11, 27). Sobolev (1928, pp. 23-25) summarised Amalitsky's concepts, but also criticised some of his conclusions: "This correlation is explained by the fact that great fluctuations in the Earth's crust, reflected in the change of the Earth's surface, provided a new distribution of water and land, new combinations in the connection - earlier disconnected belonging to different biogeographical areas - oceanic and continental spaces and in general have determined the change of the entire physical and geographical environment associated by climate changes. All of that should strongly impact on changes in the organic world. < . .> In Amalitsky's opinion, oceanic space decreased continuously from Cambrian time onwards, thus slowly extending continental space $\langle\ldots>$, but we know now that on Earth the extension of continental space due to a decrease of oceanic space was not continuous from earlier epochs, because of geocratic (i.e., predominance or enlargement of land areas in relation to oceanic areas) periods 
when land was widely changed by tallasocratic pulses that characterised encroachment of the sea onto former land".

However, Amalitsky's notion that biological evolution was punctuated by tectonic events provided some kind of impulse to his student Dmitry Sobolev, but it should be borne in mind that Amalitsky never was a proponent of catastrophism, but rather thought that all ecological events played an additional role in evolution. Based on Amalitsky's experience and his own observations, Sobolev took up the study of different aspects of the evolution of Earth's biosphere in connection with abiotic events. Until the end of his life he considered this aspect of his contributions to have been the most important.

\section{Sobolev's Contributions}

Between 1914 and 1928, Sobolev published a series of papers (Fig. 7) in which he carefully studied the geological conditions that exist(ed) during changes in earth's ecosystems. In those papers, he referenced a rich body of literature dating back to ancient times. In particular, he cited seminal works on catastrophism, such as those by Cuvier published in1812. Because of his highly inspiring publications, Sobolev gained recognition as the creator of the theory of synthetic neocatastrophism (sensu Kolchinsky, 2001, 2002).

In the first of his papers (1914a, 1915), Sobolev criticised the orthodox uniformitarianism proposed by Lyell (1830-1833) which focused on a steady-state terrestrial system. Based mainly on the recent revision of the Palaeozoic Series by the American geologist E.O. Ulrich (1911; summarised by Hahn, 1912), Sobolev stressed the unsteady and punctuated (or pulsating) nature of geological history, culminating in high-energy diastrophic revolutions with increased volcanism (see also Sobolev, 1926, 1928, 1935, 1948). With an emphasis on the evolutionary history of cephalopods, he linked causally - in general terms - biotic turnovers and turning points with diastrophic rhythmicity, rooted in the old paroxysmal model of Élie de Beaumont (18291830).

This critical theme (that biotic turnovers are related to tectonic events) was later refined from a biological viewpoint in the relatively well-known monograph issued in 1924 (Sobolev, 1924), as a punctualistic evolutionary theory of historical biogenetics. In fact, this was thought of as a synthesis of previous gradualistic (e.g., Lamarck, Darwin) and catastrophic (Cuvier) evolutionary theories (see also Sobolev, 1927b, 1929, 1935). The original model, considered commonly as overall anti-Darwinian, has been carefully reviewed recently by Popov (2008). One characteristic feature of crisis faunas is especially noteworthy in this context: evolutionary reversals during sub-lethal environmental stress episodes (called catabasis by Sobolev). This idea corresponds to recent models of retrograde evolution (e.g., Guex, 2016), whilst such phenomena as dwarfism are clearly related to the 'Lilliput effect' caused by food shortage and bioproductivity decline (e.g., Twitchett, 2001). Significantly, Sobolev also recognised four great faunal crises in the Phanerozoic (= organic catastrophes or revolutions), namely at the end of the Ordovician, Devonian, Triassic and Cretaceous, supplemented by a glacial megafaunal demise, and later by several other second-order turnovers (Sobolev, 1927b, 1928; Fig. 8 here).

At Kiev, in 1926-1928, Sobolev issued a three-part dissertation, entitled Earth and Life, that contained a remarkably detailed scenario of harmonious global evolutionary processes of earth and biosphere, controlled by orogenic cycles with catastrophic volcanic eruptions as prime triggers (Fig. 9a). In the third part (On the causes of extinction of organisms), he comprehensively considered possible causes of extinction (summarised also in a popular-science article in Priroda; Sobolev, 1927a). Despite the fact that these main principles were out-

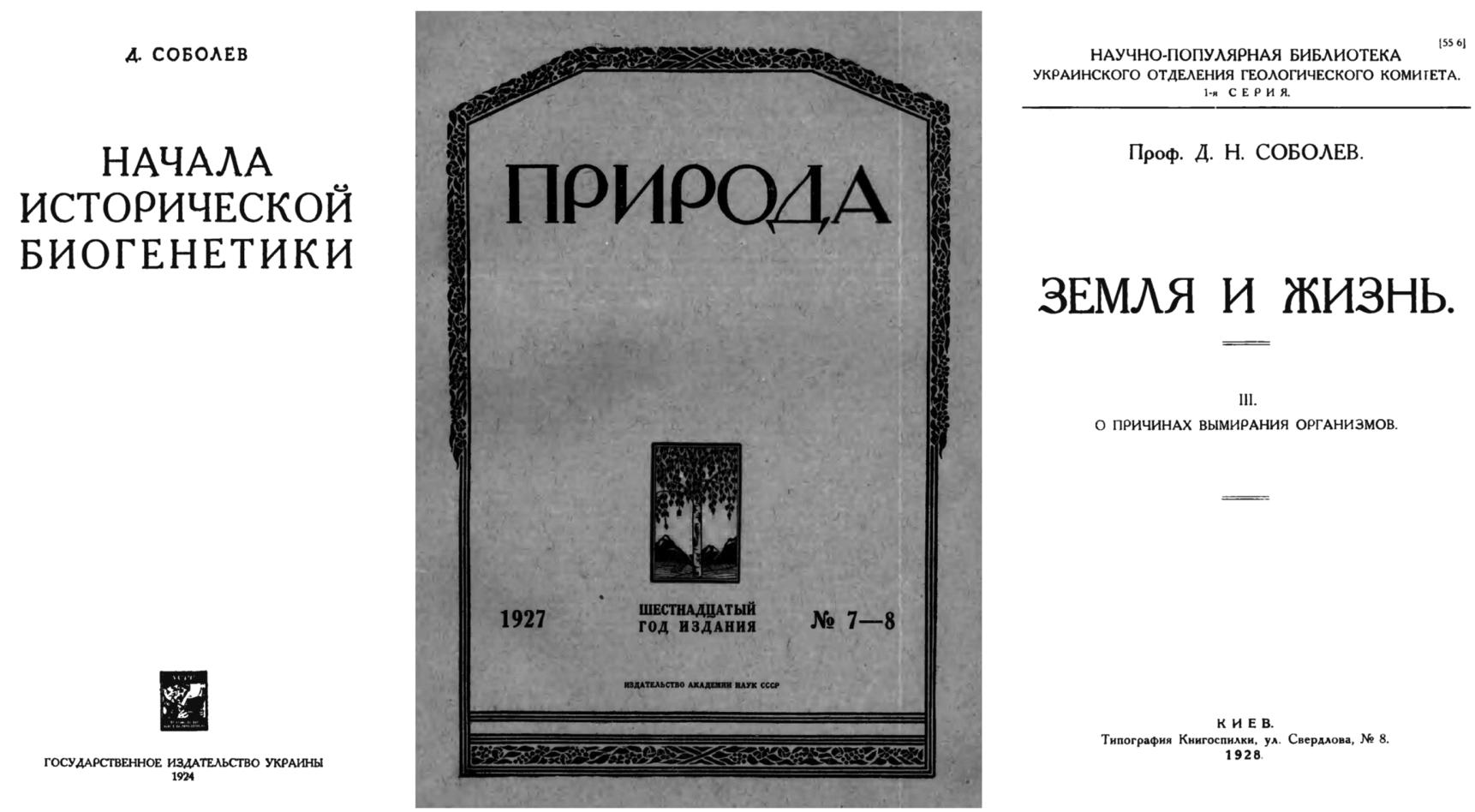

Figure 7. Title pages of Sobolev's key books (1924, 1928) and of the Soviet popular-science journal Priroda (1927). 


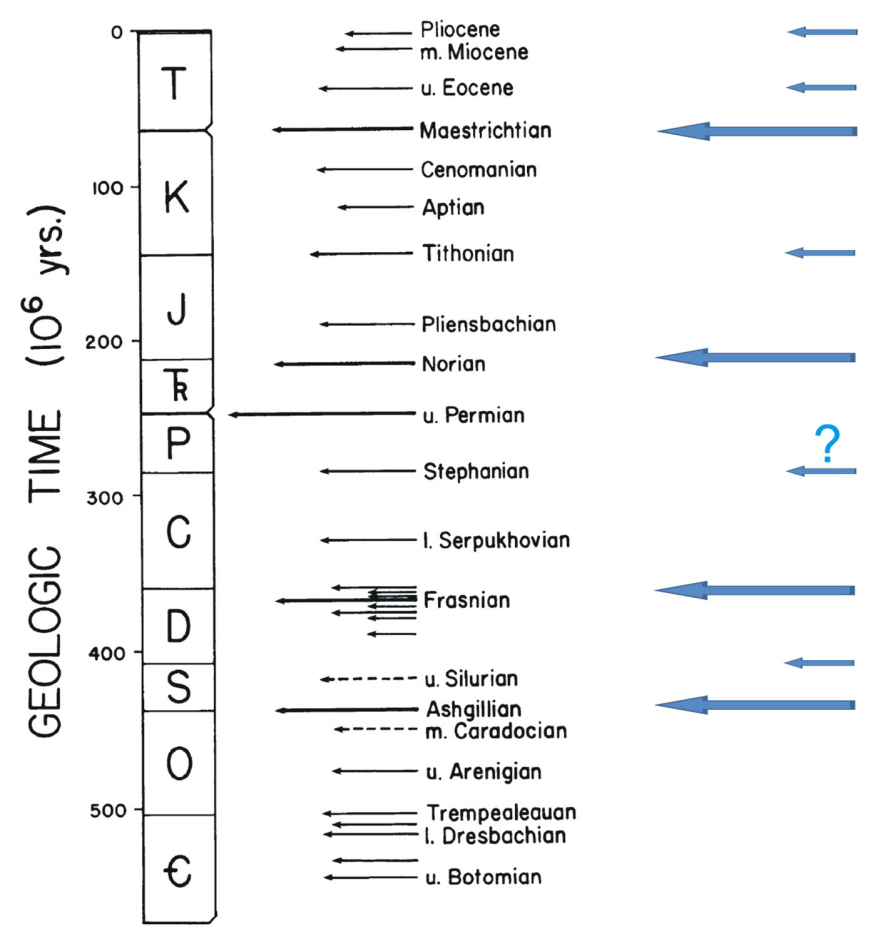

Figure 8. Major and minor extinction events in the Phanerozoic faunal record as established by Sobolev (blue arrows by Sobolev, 1924, 1927a,b, 1928, 1928), plotted against the temporal distribution of biotic crises (black arrows), as statistically identified by Sepkoski (1986, Fig. 3) in the Phanerozoic marine record. The lengths of the arrows correspond to the relative magnitudes of the global events concerned. lined in lectures in 1923, Sobolev himself pointed out that he was inspired by his contemporary, Aleksey P. Pavlov, Professor of Geology and Palaeontology at the University of Moscow, who first demonstrated the killing potential of hydrochemical changes caused by toxic volcanic gas emissions $\left(\mathrm{SO}_{2}\right.$ and $\mathrm{HCl}$; an analogue of acid rain; Pavlov 1924). Furthermore, Pavlov also noted the probability of volcanic causation of the end-Permian ecosystem collapse (now known to be so). This notion was not adopted by Sobolev, who probably was guided by the low diversity loss in the bivalve and vertebrate record through the Permian (Sobolev, 1924, p. 187; Fig. 9b here). For that reason, he consequently included the Triassic into the Upper Palaeozoic (as the 'Carboniferous-Triassic Neo-Palaeozoic era'; Sobolev, 1914a, 1915, 1926).

Sobolev made a careful study of the possible causes of these largescale ecosystem perturbations, and first put forward an advanced scenario of a cataclysmic volcanic eruption (breath of the Earth) as the main trigger of global stress via climatic and chemical changes in the atmosphere and hydrosphere. In the very novel physiological and biogeochemical aspects of this scenario, he was guided specifically by empirical data published by the American biologist, Jacques Loeb, paired with the integrated system (Gaia-type) models of Vladimir I. Vernadsky (e.g., Loeb, 1906; Vernadsky, 1926). Thus, as emphasized by Racki (2014), Sobolev reasonably fought the uniformitarian dogma using truly actualistic arguments.

The following three principal elements of the scenario need to be mentioned in particular:

- Sobolev focused on the high likelihìood of a serious disruption of the subtle gaseous equilibrium between earth and life as a result of violent volcanic paroxysms. An increased supply of carbon dioxide
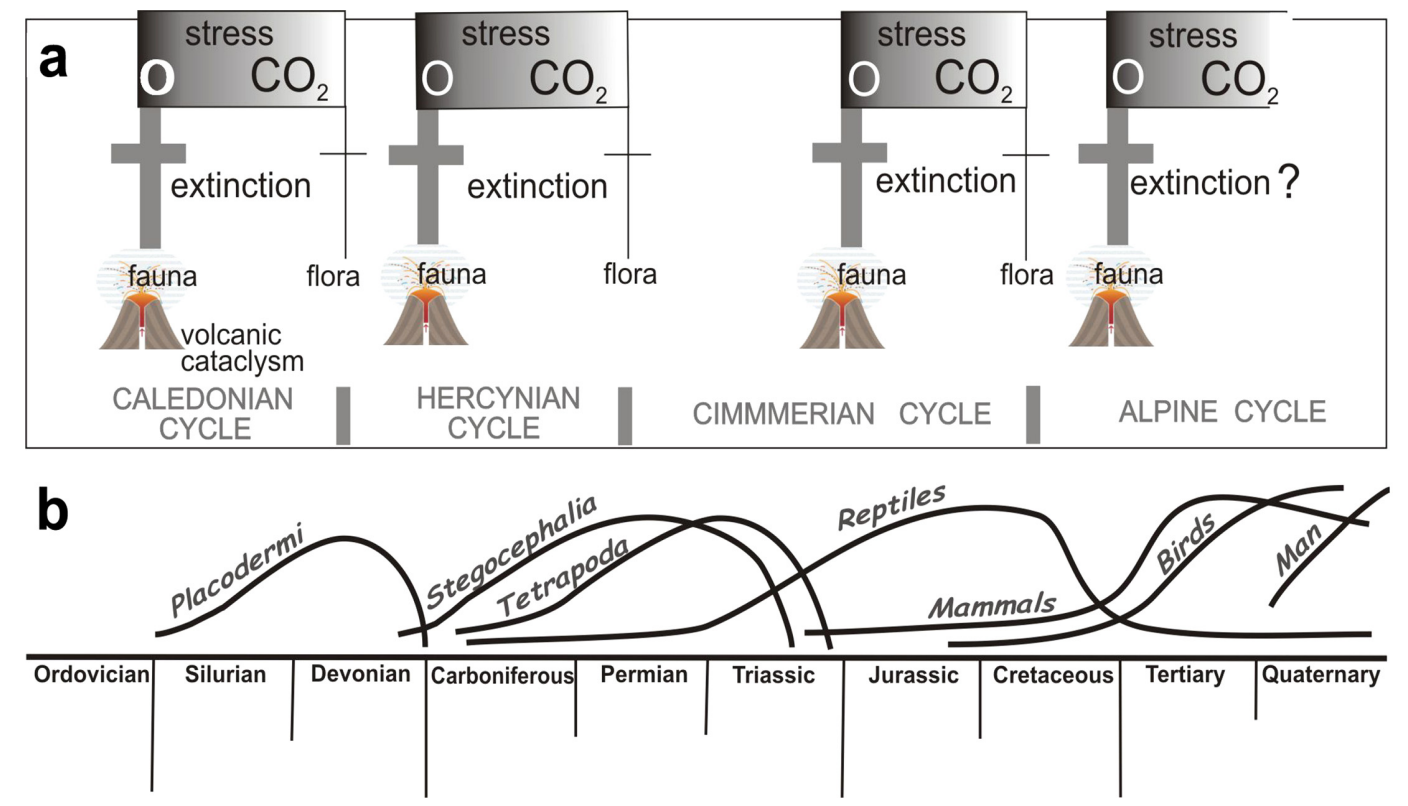

Figure 9. Scheme of evolution of vertebrate faunas as a biodiversity record of the geobiological cyclicity (after Sobolev, 1924, Fig. 8; compare Fig. 4 in Lichkov, 1965, see also Seidlitz, 1920) (a), and a schematic presentation of volcanism-controlled cyclic evolution of the Phanerozoic biosphere, as considered by Sobolev (1927a, 1928) (b). Note the long-term progressing mechanism of biotic turnover, its distinctive location within the diastrophic cycle and different killing factors responsible for diachronous extinction of fauna (onset of orogenic activity with volcanic outburst, resulting in atmospheric oxygen deficit or famine, sensu Sobolev) and flora (final orogeny, paired with increased CO${ }_{2}$ starvation). Remarkably, only the Hercynian cycle fully documents this scenario, exemplified by the progressive $\mathrm{CO}_{2}$ sink in global coal deposits and intensive biocalcification. 


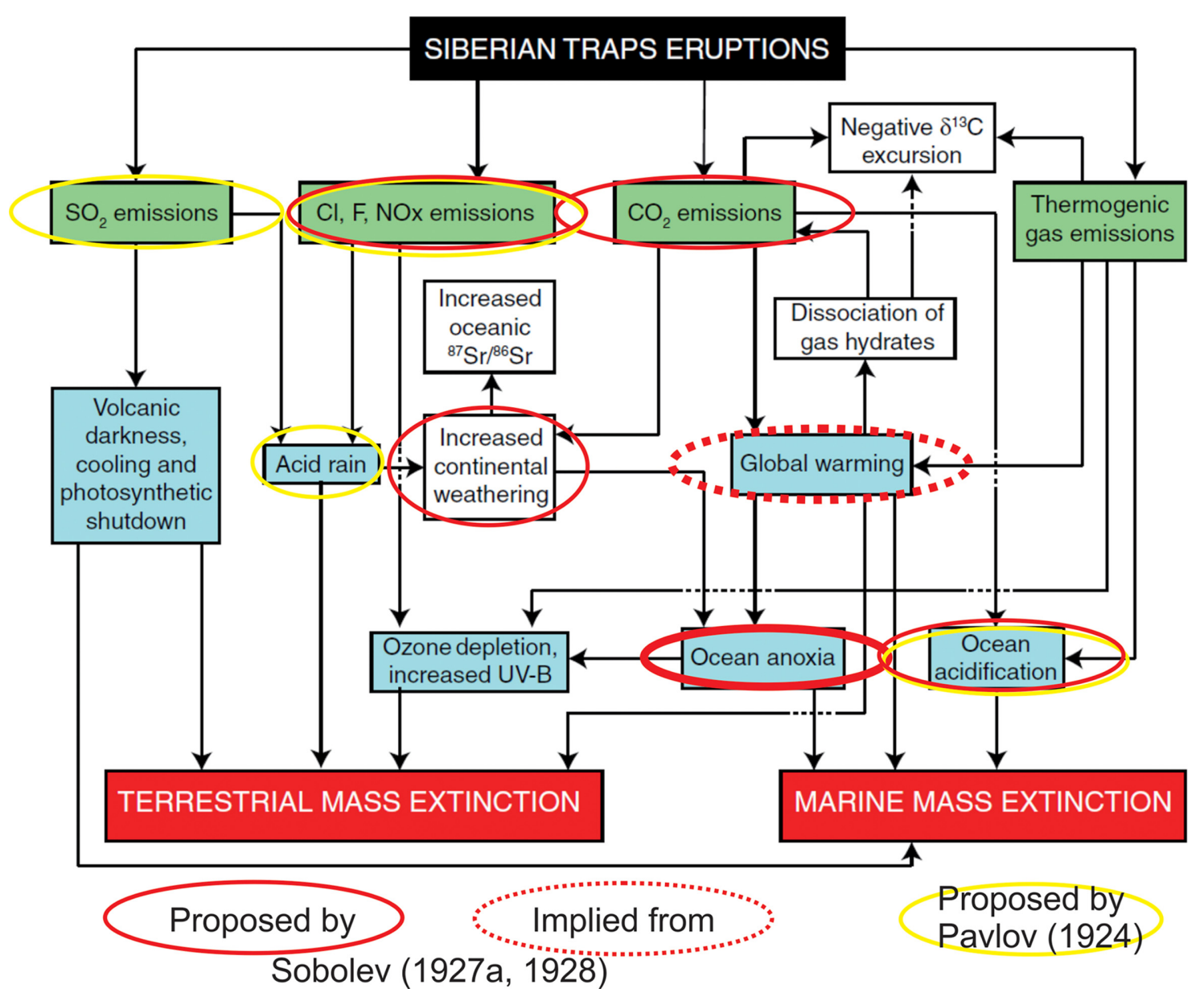

Figure 10. Volcanic super-greenhouse scenario summarised by Bond and Wignall (2014, Fig. 7), paired with presentation of mechanisms and feedbacks recognised by Pavlov (1924) and Sobolev (1927a, 1928). The flow chart shows the proposed cause-and-effect links as exemplified by the end-Permian biotic crisis promoted by Siberian volcanic cataclysm. Green boxes - direct effect of volcanic eruption; blue boxes - proxy kill mechanisms (UV-B - ultraviolet-B radiation). Note that Pavlov and Sobolev highlighted oceanic acidification due to $\mathrm{SO}_{2}$ and $\mathrm{Cl}$ emissions, even if Sobolev clearly preferred a model of biotic perturbances resulting from increased $\mathrm{CO}_{2}$ content in atmosphere; however, Sobolev did not explicitly link the killing warming stimulus with the magmatic outgassing oversupply of greenhouse gases.

and probably water vapour (also $\mathrm{SO}_{2}, \mathrm{~N}, \mathrm{NH}_{3}, \mathrm{H}_{2} \mathrm{~S}$ ) was coupled with a widespread oxygenation of emanated gases that collectively lowered levels of atmospheric oxygen (see Fig. 10). The combined processes finally led to anoxic conditions (referred to by Sobolev as oxygen starvation), and severe ionic ratio perturbations in sea water, also as a result of increased chemical weathering, promoting input of $\mathrm{Ca}$ and $\mathrm{Mg}$ from land to sea (cf. hypercapnia in recent terminology). In addition, the aqueous concentration of hydroxyl and hydrogen ions changed, and all the biogeochemical factors potentially disrupted the dynamic steady state in the biosphere, having a negative impact on faunal fertility.

- Sobolev stressed different factors of abrupt faunal and floral destruction within long-lasting "turnover epochs" (50-80 myr; Fig. $9 \mathrm{~b}$ here). This diachronistic calamity was thought to be linked to controls by lowered contents of different atmosphere gases key for life (i.e., oxygen and carbon dioxide), which would have developed systematically throughout the evolving diastrophic cycle (scenario of competition for gas).

- In the climate context, Sobolev precluded abrupt temperature drops as a decisive killing factor (following Amalitsky; Sobolev, 1924, p.
190), and pointed out the warm and humid climatic modes at times of revolutionary faunal changes. The conclusive passage is as follows: In the conditions of starvation, animals are very sensitive to physical influences, among other agents, to temperature. And, apparently, not cold, as is often thought, but excessive heat threatens organisms with more impending death. J. Loeb showed that the life expectancy of living systems, deprived of normal development, much shorter near the upper temperature boundary than at lower temperatures (...) epochs of the great extinctions - at the end of Ordovician, Devonian, Triassic and Cretaceous - anyway were not cold, but rather hot (Sobolev, 1928, p. 580-581).

In summary, Sobolev's model for the driving mechanism behind biotic change is a direct link to the volcanic summer or super-greenhouse model, which is so popular nowadays (see summary in Bond and Wignall, 2014; Fig. 10 here). Amazingly, Sobolev did not discuss the obvious link between the volcanic releases of excess $\mathrm{CO}_{2}$ (strongly emphasized in his model) and increased warming. Note, however, that the highlighted Arrhenius's (1896) theory of volcanogenic carbon dioxide control of the greenhouse effect was commonly ignored at 
the time (e.g., Brooks, 1926; for review see Fleming, 1998), even if this concept was originally well known to Sobolev (1914a).

\section{Summary and Final Remarks}

From the above review it is clear that we should remember our precursors, especially those beyond the English-speaking world... Amalitsky, and especially Sobolev, were the first amongst Russian scientists who started to integrate analyses of periodic geological processes with the record of an evolving biosphere, with a particular focus on the causes of mass extinctions. Similar catastrophic models, focused on extreme greenhouse effects due to large-scale outpouring of plateau basalts, were developed in the mainstream literature more than 50 years later in the context of actualistic neocatastrophism (e.g., Keith, 1982; see summary in Racki, 2014). Sobolev's models in fact originated at a time when the volcanism-focused debate was limited to the question of whether volcanic dust might have contributed to climatic cooling (for a review see Fleming, 1998).

Sobolev, inspired by Amalitsky, can be seen indeed as the conceptual forerunner of the modern science of mass extinction and evolutionary catastrophes (e.g., Courtillot, 1999), jointly with a palaeophysiological approach to understanding global ecosystem changes (Knoll et al., 2007; Pörtner, 2008). Sobolev discussed four main biodiversity crises in earth history. He missed, however, "the Mother of all Mass Extinctions" at the end of the Palaeozoic Era (Fig. 9b). Also he was generally mistaken in that he equated the Late Devonian mass extinction with the Devonian-Carboniferous boundary rather than with the Frasnian-Famennian boundary.

Shortly before his death Dmitry Sobolev wrote, in frustation: What of [my] works is overall accepted, it does not present the scientific merit, but what I consider to be the most important, this is not acknowledged by others or indeed is rejected (quoted from an unpublished manuscript dated 1943; Ozonkowa, 1980, p. 140). In fact, Sobolev was known in the Soviet Union at the time, and he is still mostly known in Russia today, merely as a palaeontologist and regional geologist (see for example, a memorial note by Yakovlev, 1955). Serious criticism of Sobolev's ideas, that focused on his "heretical" evolution theory (Popov, 2008), continued until the late 1990s. When non-catastrophic trends predominated in Russia, the global geological ideas of Amalitsky and Sobolev were either ignored (starting with the creator of the term "neocatastrophism"; Schatski, 1937) or noted merely for their historical value (e.g., Obruchev, 1932; Balmasova, 1939; Nalivkin, 1958; Stepanov, 1959; Davitashvili, 1969; Vysotsky, 1977; Rezanov, 1984; Budyko et al., 1988; Khain, 2003; Gladenkov and Kuznetsova, 2005; but see also an exceptional case in mainstream literature Hoffman, 1989). For example, the discussion of the volcanism-induced extinction processes by Dyssa et al. (1960) was confined to poisonous radioactive elements... Sobolev's concept of geological cyclicity was even disapproved of in 1935 from a "dialectic" perspective (see reply in Sobolev, 1935).

Amalitsky's Pangea-like concept of biogeography was remarkabkly cited in the late English edition of the magnum opus by the great Austrian geologist Eduard Suess, in the context of the well-known Gondwana discussion (Suess, 1904-1909; see review in Thenius, 1981; Nield, 2007). However, in the several contemporary and later mono- graphs it was totally ignored, as exemplified by Wegener's milestone palaeogeographic compilation of Pangea (Wegener, 1920; also Arldt, 1907; Kossmat, 1908; von Zittel, 1901, p. 458; Dacqué, 1915, p. 321).

Only Lichkov (1931, 1965) further developed Amalitsky's and Sobolev's ideas, and their heuristic value was clearly demonstrated by Kolchinsky $(2001,2002)$. This change is also more or less manifested in several more modern works (e.g., Zhdanov et al., 2000; Martynov, 2012; Panichev and Gulkov, 2012), and the revival is also seen in the recent re-issue of some works by Sobolev (1914a, 1924, 1927a). As noted by Kolchinsky (2002, p. 306): Now, when the publications, focused on the sudden speciation and global turnovers by some planetary factors of cosmic (asteroid explosion, collision with a comet, supernova blast) or terrestrial origin (volcanism, orogenesis, transgression), they are calculated by the thousands, it is appropriate to recall the name D.N. Sobolev.

Of course, the fate of being forgotten not only affected Amalitsky and Sobolev, but also other scientists such as Pavlov and Mikhail A. Usov, a young Siberian geologist from Tomsk University who discussed as early as 1916 a worldwide catastrophe as a result of a traptype volcanic eruption and meteorite impacts (see Usov, 1916; Racki, 2014). The attractive working hypotheses put forward by the visionary Russian scholars, forgotten for many generations, are now widely propagated (Ager, 1993; Courtillot, 1999; Palmer, 2003; Nield, 2007; see also Racki, 2015), and are prominent examples of being 'ahead of their time' (see Hook, 2002). The present note should be seen as a step towards recognizing their proper place in the history of science.

\section{Acknowledgements}

We are grateful to Professors Karen Severud (University of Kansas, Lawrence) and John Diemer (University of North Carolina at Charlotte, Charlotte) for critical reviews and to John W.M. Jagt (NHM Maastricht) for linguistic corrections and critical comments.

\section{References}

Ager, D.V., 1993, The new catastrophism: the importance of the rare event in geological history: Cambridge University Press, Cambridge, $252 \mathrm{p}$.

Amalitskaya, A.P., 1925, Professor Vladimir Prokhorovich Amalitsky: Notes of North-Dvina Society of the Study of the Local Region, Issue 1, Great Ustiug, Sovmysl Press, pp. 1-4. (in Russian)

Amalitsky, V.P., 1885, Gorbatov uyezd. Report to the Nizhnenovgorod guberniya zemstvo: Sankt-Peterburg, Materials to the Land Evaluation in the Nizhnenovgorod guberniya, v. 7, 263 p. (in Russian)

Amalitsky, V.P., 1886, Carboniferous and Permian systems of the Nizhnenovgorod guberniya: Sankt-Peterburg, Materials to the Land Evaluation in the Nizhnenovgorod guberniya, v. 13, pp. 1-216. (in Russian)

Amalitsky, V.P., 1887, Permian deposits of the Oka-Volga basin (Nizhnenovgorod guberniya): Sankt-Peterburg, E. Evdokimov's Printing House, 209 p. (in Russian)

Amalitsky, V.P., 1890a, Particoloured rocks of the Oka-Volga basin: VIII Meeting of the Russian Naturalists and Medicines Society in SanktPeterburg, $4^{\text {th }}$ Department: Geology and Mineralogy, Abstracts, Proceedings of the Sankt-Petersburg Society of Naturalists, pp. 1-2. (in Russian)

Amalitsky, V.P., 1890b, About the fauna from the particoloured marls from the Oka-Volga basin: VIII Meeting of the Russian Naturalists and 
Medicines Society in Sankt-Peterburg, $4^{\text {th }}$ Department: Geology and Mineralogy, Abstracts, Works of the Sankt-Petersburg Society of Naturalists, p. 4. (in Russian)

Amalitsky, V.P., 1892, Materials to the knowledge of the Permian fauna of Russia. I. Anthracosidae: Warsaw, Warsaw Society of Naturalists Press, 151 p. (in Russian)

Amalitsky, V.P., 1895a, Some notes about Upper Permian continental sediments of Russia and South Africa: Proceedings of the Warsaw Society of Naturalists (6), v. 7, pp. 117-126. (in Russian)

Amalitsky, W.A., 1895b, A comparison of the Permian freshwater Lamellibranchiata from Russia with those from the Karroo-System in South Africa: Quartery Journal of the Geological Society of London, v. 51, no. 3, pp. 337-351.

Amalitsky, V.P., 1896, About the geological development of organisms and Earth relief: The speech prepeared by Professor V.P. Amalitsky for the special act at the Warsaw Imperial University on the August 30, 1896, $31 \mathrm{p}$.

Amalitsky, V.P., 1897, Geological excursion to the north of Russia in 1896. IV. About new palaeontological finds from Permian marly-sandy rocks of Sukhona and small northern Dvina: Proceedings of the Warsaw Society of Naturalists (1), v. 8, pp. 1-7. (in Russian)

Amalitsky, V.P., 1900, Geological excursion to the north of Russia. VII. About excavations of vertebrate animal remains from Permian deposits in the north of Rusia in 1899: Proceedings of the Warsaw Society of Naturalists, 11, pp. 177-190. (in Russian)

Amalitsky, V.P., 1901a, Excavation of ancient vertebrate animals in the north of Russia: The peace of God, (1), v. II, p. 71-82. (in Russian)

Amalitsky, V.P., 1901b, About new sauridae collected from the Permian deposits, distributed along the North Dvina River: Sankt-Peterburg, Diary of XI Meeting of the Society of Russian Naturalists and Physicians, 9, p. 380. (in Russian)

Amalitsky, V.P., 1903, Follow the Arctic Ocean and River Pechora: Warsaw, Warsaw Institute of Deaf and Blind Press (reprint Sankt-Peterburg, Alphabet Press, 2012, 118 p.). (in Russian)

Amalitsky, V.P., 1921a, Dvinosauridae: Petrograd, Professor V.P. Amalitsky's excavations at the Northern Dvina River, v. 1,20 p. (in Russian)

Amalitsky, V.P., 1921b, Seymouridae: Petrograd, Professor V.P. Amalitsky's excavations at the Northern Dvina River, v. 2, 17 p. (in Russian)

Amalitsky, V.P., 1922a. Report about the excavations at the Northern Dvina River in 1914: Proceedings of the Geological and Mineralogical Museum, v. 3, no. 3, pp. 113-117. (in Russian)

Amalitsky, V.P., 1922b, Diagnoses of the new forms of vertebrates and plants from the Upper Permian on Northern Dvina: Izvestia RAN, pp. 329-340. (in Russian)

Amalitsky, V.P., 1927, Anna petri gen. et sp. nov., therocephale from the northern Dvina River: Leningrad, Professor V.P. Amalitsky's excavations at the northern Dvina River, v. 5, 10 p. (in Russian)

Amalitsky, V.P., 1931, Diary of the observations at the small northern Dvina River: Leningrad, Professor V.P. Amalitsky's excavations at the northern Dvina River, v. 6, pp. 13-57. (in Russian)

Amalizky, W.P., 1892, Ueber die Anthracosien der Permformation Russlands: Palaeontographica, v. 39, pp. 125-214.

Arldt, T., 1907, Die Entwicklung der Kontinente und ihrer Lebewelt, ein Beitrag zur vergleichenden Erdgeschichte: Leipzig, W. Engelmann, $729 \mathrm{p}$.

Arrhenius, S., 1896, On the influence of carbonic acid in the air upon the temperature on the ground: Philosophical Magazine, v. 41, pp. 237-276.

Balmasova, S.A., 1939, To the question of the causes of extinction of organisms in the past geological epochs: Scientific Notes of MSHI, Department of Geology, n. 1, pp. 195-220. (in Russian)

Berg, L.S., 1922, Nomogenesis or evolution based on regularities: SanktPeterburg State Press, 306 p. (in Russian)

Berg, L.S., 1977, Works on the evolution theory (1922-1930): Leningrad, Nauka, 387 p. (in Russian)

Bond, D.P.G., and Wignall, P.B., 2014, Large igneous provinces and mass extinctions: an update. in Keller, G., and Kerr, A.C. (eds.), Volcanism, Impacts, and Mass Extinctions: Causes and Effects: Geological Society of America, Special Paper, 505, pp. 339-352.

Brooks, C.E.P., 1926, Climatic changes during geological times: Nature, v. 118 , no. 2958, pp. 53-55.

Budyko, M.I., Golitsyn, G.I., and Izrael, Y.A., 1988, Global climatic catastrophes: Springer-Verlag, Berlin, 99 p.

Courtillot, V., 1999, Evolutionary catastrophes: the science of mass extinction: Cambridge University Press, Cambridge, 173 p.

Cuvier, G., 1812, Discours préliminaire. in Cuvier, G. (ed.), Recherches sur les Ossemens Fossils, v. 1: Déterville, Paris, pp. 1-116.

Dacqué, E., 1915, Grundlagen und Methoden der Paläogeographie: Gustav Fischer, Jena, $499 \mathrm{p}$.

Davitashvili, L.S., 1969, Causes of organism extinction: Moscow, Nauka, 437 p. (in Russian)

Dokuchaev, V.V., 1886, Basic moments in the history of the valualities of the territories at European Russia, with classification of Russian soils: Materials to the Land Evaluation in the Nizhnenovgorod guberniya. Nature-historical part: Report for the Nizhnenovgorod guberniya, v. 1, Sankt-Peterburg, E. Eudokimov's print, 391 p. (in Russian)

Dyssa, F.M., Nesterenko, N.G., and Stovas, M.V., 1960, On causes of extinction of large groups of organisms: Doklady AN SSSR, v. 131, pp. 185-187. (in Russian)

Efremov, I.A., 1960, Vladimir Prohorovich Amalitsky (100 years birthday anniversary): Paleontological Journal, n. 4, pp. 1-15 (in Russian).

Élie de Beaumont, L., 1829-1830, Recherches sur quelques-unes des révolutions de la surface du globe: Annales des Sciences naturelles, v. 18 , no. 1829 , pp. 5-25, 284-416; v. 19, no. 1830, pp. 5-99, 177-240.

Fleming, J.R., 1998, Historical perspectives on climate change: Oxford University Press, New York, 194 p.

Gladenkov, Y.U., and Kuznetsova, K.I. (eds.), 2005, Biosphere-ecosystem-biota in earth history: paleobiogeographic aspects. To 100-years birthday anniversary of academic V.V. Menner: Nauka, Moscow, 512 p. (in Russian)

Guex, J., 2016, Retrograde evolution during major extinction crises: Springer International Publishing, Switzerland, Cham, $77 \mathrm{p}$.

Hahn, F.F., 1912, E. O. Ulrich's "Revision der Paläozoischen Systeme" ein Markstein der Stratigraphie als Wissenschaft?: Geologische Rundschau, v. 3, pp. 544-556.

Hoffman, A., 1989, Changing paleontological views on mass extinction phenomena. in Donovan, S.K. (ed.), Mass Extinctions: Processes and Evidence: Belhaven, London, pp. 1-18.

Hook, E.B. (ed.), 2002, Prematurity in scientific discovery: on resistance and neglect: University of California Press, Berkeley, 377 p.

Keith, M.L., 1982, Violent volcanism, stagnant oceans and some inferences regarding petroleum, strata-bound ores and mass extinctions: Geochimica et Cosmochimica Acta, v. 46, pp. 2621-2637.

Khain, V.E., 2003, Principal problems of recent geology, issue 2: Nauchnyj Mir, Moskva, 346 p. (in Russian)

Knoll, A.H., Bambach, R.K., Payne, J.L., Pruss, S., and Fischer, W.W., 2007, Paleophysiology and end-Permian mass extinction: Earth and Planetary Science Letters, v. 256, pp. 295-313

Kolchinsky, E.I., 2001, D. N. Sobolev - Begründer der ersten Konzeption des synthetischen Neokatastrophismus: Darwinismus und/als Ideologie: Verlag für Wissenschaft und Bildung, Berlin, pp. 168-178.

Kolchinsky, E.I., 2002, Neocatastrophism and selectionism. The eternal dilemma or the opportunity of the synthesis? (Historical-critical notes): Nauka, Sankt Peterburg, 553 p. (in Russian)

Kossmat, F., 1908, Paläogeographie (Geologische geschichte der Meere und Festländer): Leipzig, G.J. Göschen, 136 p.

Lichkov, B.L., 1931, Dvizhenie materikov i klimaty proshlogo Zemli: Leningrad, Izd-vo Akademii nauk SSSR, 133 p. (in Russian)

Lichkov, B.L., 1965, To the foundations of modern theory of the earth: Leningrad University Press, Leningrad, $120 \mathrm{p}$. (in Russian)

Loeb, J., 1906, The dynamics of living matter: Columbia University Press, 
New York, $233 \mathrm{p}$.

Lyell, C., 1830-1833, Principles of geology; being an attempt to explain the former changes of the Earth's surface, by reference to causes now in operation (3 volumes): John Murray, London.

Martynov, A.V., 2012, Ontogenetic systematics: the synthesis of taxonomy, phylogenetics, and evolutionary developmental biology: Paleontological Journal, v. 46, pp. 833-864.

Nalivkin, D.V., 1958, Geological catastrophes: Priroda, v. 47, pp. 27-32. (in Russian)

Nield, T., 2007, Supercontinent: Ten Billion Years in the Life of Our Planet: Harvard University Press, Cambridge, $288 \mathrm{p}$.

Obruchev, V.A., 1932, Obrazovanie gor i rudnykh mestorozhdeniǐ: Izd-vo Akademii nauk SSSR, Leningrad, 149 p. (in Russian)

Ozonkowa, H., 1980, Problemy paleozoiku Gór Świętokrzyskich w pracach Dymitra Nikołajewicza Sobolewa: Prace Uniwersytetu Śląskiego, v. 192, Geologia, v. 2, pp. 139-228.

Palmer, T., 2003, Perilous planet Earth. Catastrophes and catastrophism through the ages: Cambridge University Press, Cambridge, $536 \mathrm{p}$.

Panichev, A., and Gulkov, A.K., 2012, Absolute and man: Moscow, Printing House FOLIUM, 342 p. (in Russian)

Pavlov, A.P., 1924, On some still insufficiently studied factors of the extinction of the animals. in Pavlova, M.V. (ed.), Cases of the Extinction of the Animals in Past Geological Epochs: Moscow State Print House, Moscow, pp. 89-130. (in Russian)

Popov, I., 2008, Orthogenesis versus Darwinism: the Russian case: Revue d'Histoire des Sciences, v. 61, pp. 367-397. http://www.cairn.info/ revue-d-histoire-des-sciences-2008-2-page-367.htmRussia\#no1

Pörtner, H.O., 2008, Ecosystem effects of ocean acidification in times of ocean warming: a physiologist's view: Marine Ecology Progress Series, v. 373, pp. 203-217.

Racki, G., 2014, Dmitri Sobolev and other forgotten forerunners of mass extinction science and volcanic catastrophism: Acta Palaeontologica Polonica, v. 59, pp. 1006-1008.

Racki, G., 2015, Catastrophism and neocatastrophism versus cosmic hazard: Ager versus Alvarez; Cuvier versus Laplace: Palaios, v. 30, pp. 432434

Racki, G., Koeberl, C., Viik, T., Jagt?Yazykova, E.A., and Jagt, J.W.M., 2014, Ernst Julius Öpik's (1916) note on the theory of explosion cratering on the Moon's surface. The complex case of a long-overlooked benchmark paper: Meteoritics \& Planetary Science, v. 49, pp. 18511874.

Rezanov, I., 1984, Great catastrophes in Earth history: Moscow, Nauka, 176 p. (in Russian)

Schatski, N.S., 1937, About neocatastrophism: Problemy Sovetskoj Geologii, v. 7, pp. 532-551. (in Russian)

Seeley, H.G., 1899, On fossil reptiles from the governments of Perm and Vologda: Compte Rendu de la VII Session du Congrès Géologique Internationale, Petersbourg 1897, $179 \mathrm{p}$.

Seidlitz, W. von, 1920, Revolution in der Erdgeschichte: Jena, G. Fischer. 420.

Sepkoski, J.J., 1986, Phanerozoic overview of mass extinctions. in Raup, D.M., and Jablonski, D. (eds.), Patterns and Processes in the History of Life: Springer, Berlin, pp. 277-295.

Sobolev, D.N., 1914a, On geological periods: Annals of Geology and Mineralogy of Russia, v. 16, no. 9, pp. 233-246. (in Russian)

Sobolev, D.N., 1914b, Sketches on the phylogeny of goniatitids: Warsaw, (reprint: Moscow, GEOS, 2015; http://paleobot.ru/pdf/Sobolev1914.pdf). (in Russian)
Sobolev, D.N., 1915, Geological periods: Priroda, v. 4, pp. 814-832. (in Russian)

Sobolev, D.N., 1924, Principles of Historical Biogenetics: Simferopol, State Ukrainian Press, 205 p. (reprint: Moscow. GEOS, 2013; http://paleobot.ru/pdf/Sobolev.pdf) (in Russian)

Sobolev, D.N., 1926, Earth and Life. 1. Geological Cycles: Science-Popular Library of the Ukrainian Department of the Geological Committee, Kiev, 59 p. (in Russian)

Sobolev, D.N., 1927a, Diastrophism and organic revolutions: Priroda, v. 16, pp. 565-582. (re-issued in Lethaea rossica, 2013, v. 8, pp. 35-42. http:// paleobot.ru/pdf/4-6 2013 8.pdf) (in Russian)

Sobolev, D.N., 1927b, Earth and Life. II. Evolution and Revolutions in the History of the Organic World: Science-Popular Library of the Ukrainian Department of the Geological Committee, Kiev, 38 p. (in Russian)

Sobolev, D.N., 1928, Earth and Life. III. On the Causes of Extinction of Organisms: Science-Popular Library of the Ukrainian Department of the Geological Committee, Kiev, 74 p. (in Russian)

Sobolev, D.N., 1929, Evolution as organismal growth: Priroda, v. 18, pp. 437-454. (in Russian)

Sobolev, D.N., 1935, On geological cycles and dialectics in geology: Problemy Sovietskoj Geologiii, v. 5, pp. 648-656. (in Russian)

Sobolev, D.N., 1948, The main regularities of the Earth and life: Zapiski Nauchno-Issledoviateskogo Instituta Geologii, v. 9, pp. 5-10. (in Russian)

Solovyev, V.O., Moskalenko, I.A., and Shcherbina, V.G., 2014, Kharkov geological school; its role in exploring and developing oil and gas fields: National Technical University, Kharkov, 128 p. (in Russian)

Stepanov, D.L, 1959, Neocatastrophism in today's paleontology: Paleontologicheskii Zhurnal, v. 4, pp. 11-16. (in Russian)

Suess, E., 1904-1909, The Face of the Earth, translated by H.B.C. Sollas (4 volumes): Clarendon, Oxford.

Thenius, E. von, 1981, Das "Gondwana-Land" Eduard Suess 1885. Der Gondwanakontinent in erd-und biowissenschaftlicher Sicht: Mitteilungen der Österreichische Geologische Gesellschaft, v. 74/75, pp. 53-81.

Twitchett, R.J., 2001, Incompleteness of the Permian-Triassic fossil record: a consequence of productivity decline?: Geological Journal, v. 36, pp. 341-353.

Ulrich, E.O., 1911, Revision of the Paleozoic systems: Geological Society of America Bulletin, v. 22, pp. 281-680.

Usov, M.A., 1916, Catastrophes in earth history: Priroda, v. 5, pp. 437-462. (in Russian)

Vernadsky, V.I., 1926, Biosphere: Leningrad Science-Technical Press, 146 p. (in Russian)

Vysotsky, B.P., 1977, Problems of history and the methodology of geological sciences: Moscow, Nedra, 278 p. (in Russian)

Wegener, A., 1920, Die Entstehung der Kontinente und Ozeane $\left(2^{\text {nd }}\right.$ Edition): Braunschweig, Friedr, Vieweg \& Sohn, 135 p.

Yakovlev, N.N., 1955, Five years after the death of D.N. Sobolev: Annual Issue of the All-Russian Paleontological Society, v. 15. pp. 369-370. (in Russian)

Zeiller, R., 1898, Contribution à l'étude de la flore pteridotogique des schistes permiens de Lodève: Bulletin du Muséum d'Histoire naturelle de Marseille, v. 1, pp. 6-69.

Zhdanov, Ju.A., Gus'kov, E.P., and Bessonov, O.A., 2000, Cases of the species extinction: Nauchnaya Mysl Kavkaza, v. 2, pp. 3-18. (in Russian)

Zittel, K.A. von, 1901, History of geology and palæontology to the end of the ninetheenth century, translated by M.M. Ogilvie-Gordon: W. Scott, London, $562 \mathrm{p}$. 


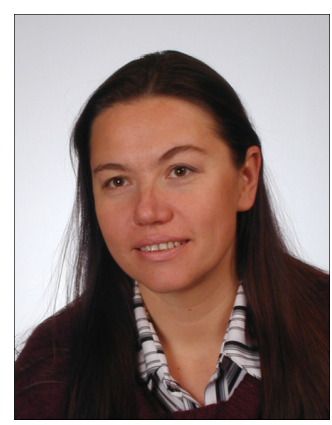

Elena A. Jagt-Yazykova is a Russian geologist and palaeontologist (graduation: Leningrad State University; candidate dissertation: Geological Faculty, Moscow State University; PhD thesis: Free University Amsterdam; Dr. Habil.: University of Silesia, Faculty of Earth Sciences). Firstemployment at VSEGEI(All Russian Scientific-Research Geological Institute, Leningrad), followed by Faculty of Earth Sciences, University of Silesia, Sosnowiec and the Laboratory of Palaeobiology, Department of Biosystematics, University of Opole, Poland. Scientific interest: mainly Cretaceous ammonite biostratigraphy and evolutionary dynamics, bioevents and palaeobiogeography, plus palaeoecology and palaeoenvironmental reconstructions.

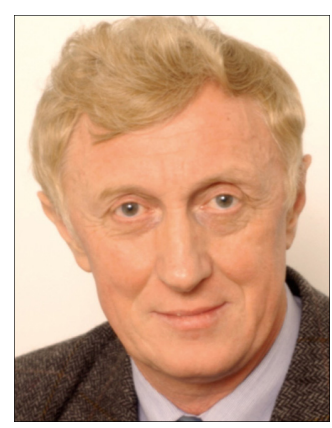

Grzegorz Racki is a Polish geologist and palaeontologist (graduation: Faculty of Geology, Warsaw University; PhD thesis: Institute of Palaeobiology, Polish Academy of Sciences, Warsaw; Dr. Habil.: Polish Geological Institute, Warsaw). He is currently the full Professor of Paleontology and Stratigraphy at the Department of Earth Sciences, Silesian University, Sosnowiec (previously Director of Institute of Palaeobiology, Polish Academy of Sciences, 2006-2010). Scientific interests: (1) integrative multidisciplinary analysis of major mass extinctions, with a special emphasis on of the Late Devonian global bio-events; (2) history of geosciences. 